\title{
A Note On The Determinants Of Equity Payouts
}

Kenneth M. Washer (E-mail: Kenneth_Washer@tamu-commerce.edu), Texas A \& M University - Commerce K. Michael Casey (E-mail: mcasey@ mail.uca.edu), University of Central Arkansas

\begin{abstract}
This study develops an equity distribution model to analyze dividend and share repurchase payments to shareholders. Transaction costs increase and agency costs decrease as equity cash distributions increase, suggesting that an optimal equity distribution exists that minimizes the sum of these two costs. A Tobit model relates the equity distribution yield (dividend and share repurchase distributions as a percent of market capitalization) to proxies of perceived undervaluation, financial leverage, asset productivity, investment cash outflows, and agency costs. The results suggest that firms appearing undervalued, using little financial leverage, employing more productive assets, having fewer investment opportunities, or having greater dispersion of ownership distribute relatively more cash to shareholders through dividends and/or share repurchases. These findings support the existence of an optimal equity cash distribution policy that is unique to each firm.
\end{abstract}

\section{Introduction}

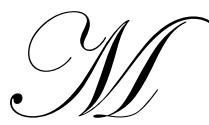

iller and Modigliani (1961) argue that dividend policy is irrelevant if capital markets are perfect. Subsequent research, such as Litzenberger and Ramaswamy (1979), contend that dividend policy is relevant due to the existence of market imperfections. Taxes are often cited as one such market imperfection deemed to impact dividend policy (Brennan, 1970; Chaplinsky and Seyhun, 1990) yet many researchers including Kalay (1982) and Miller and Scholes (1978) refute that evidence. Black (1976) maintains that dividend payout seems irrational yet exists. Miller (1986) postulates that rationality based models are not discredited, but instead that behavioral models offer promise for explaining the dividend puzzle.

If dividends are indeed behaviorally relevant, cross sectional regularities in dividend payout ratios should exist. Rozeff (1982), consistent with Jensen and Meckling (1976) agency theory, finds that regularities do exist and suggests that firms set their dividend distribution to minimize the sum of transaction costs and agency costs associated with newly issued equity. Jensen and Meckling (1976) contend that as the dividend distribution increases, a firm trades higher transaction costs for lower agency costs. Since Rozeff's dividend study, share repurchases have grown in importance as a method of distributing cash to shareholders. Stephens and Weisbach (1998) indicate that one potential benefit of a share repurchase as a method of cash distribution is that reputational penalties do not accrue to firms not completing previously announced repurchases. Netter and Mitchell (1989) find similar results. In contrast, Denis, Denis, and Sarin (1994) and Bajaj and Vijh (1990) both find substantial penalties associated with dividend reduction.

Lie and Lie (1999) find that corporate managers consider tax treatment of investor clientele when choosing between dividends and share repurchase as a means of cash disbursement. Bagwell and Shoven (1989) also find tax treatment to impact the method of cash distribution. Although much of this previous research clearly identifies the link between cash disbursement methods (dividends vs. share repurchase), no research to date investigates the existence of an optimal equity distribution model which focuses on total equity cash distributions.

This study provides evidence that firms act as if there is an optimal equity cash distribution policy when distributions to shareholders include both dividends and share repurchases. Influences on a firm's equity cash distribution policy include perceived undervaluation, financial leverage, asset productivity, investment opportunities, and agency costs. 
These results indicate that firms with lower price-to-book value ratios tend to distribute relatively more cash to shareholders, presumably to send a positive signal to investors and boost the stock price. Asquith and Mullins (1986) find that stock prices increase abnormally when a dividend increase is announced. Vermaelen (1984) and Dann (1981) each find that stock prices increase abnormally when a repurchase is announced. These results are consistent with the Koch and Shenoy (1999) finding that dividend and capital structure policies convey more predictive information for over-investing firms and under-investing firms than for firms maximizing value. Intuitively, if management correctly perceives that the firm is undervalued, repurchasing "cheap" stock will benefit long-term shareholders.

This study finds that firms having lower debt-to-asset ratios tend to distribute relatively more cash to shareholders, arguably to increase financial leverage and move the firm to a better capital structure. The trade-off model suggests that there is some optimum amount of financial leverage that is firm specific. According to this model, under-leveraged firms can increase their value by financing with relatively more debt. Paying higher dividends and/or repurchasing stock reduces equity and thus increases the debt ratio, all other things held constant.

These results indicate that firms having higher cash flow-to-total asset ratios and lower historical growth rates in sales tend to distribute relatively more cash to shareholders, presumably because they generate more than enough cash to meet investment needs. According to the residual dividend model, firms initially use net income to fund the equity portion of the capital budget. If net income exceeds the amount required, the surplus is distributed to shareholders. Firms with more productive assets and firms with fewer current investment opportunities are more likely to have a surplus, holding all other factors constant. Investment policy does appear to influence the equity cash distribution policy. ${ }^{1}$

The results of this study also indicate that larger firms tend to distribute relatively more cash to shareholders in order to reduce agency costs. Larger firms typically have more outside owners and, thus, have relatively higher agency costs. Large equity cash distributions increase the probability that managers will have to raise funds externally and thus undergo the scrutiny of new investors. These new investors will effectively monitor managers' actions through the required rate of return on equity. Ikenberry, Lakonishok, and Vermaelen (1995) also document a size effect.

\section{Equity Distribution Model}

Rozeff (1982) suggests that a firm's optimal dividend policy minimizes the sum of transaction costs and agency costs. Transaction costs (flotation costs) are incurred when a firm sells new shares of stock. These costs are minimized by initially using earnings to fund the equity portion of the capital budget. Cash will be distributed to shareholders only when earnings are greater than equity funding requirements, and new stock will be sold only when earnings are less than equity funding requirements.

Agency costs involve owner-managers consuming perquisites and engaging in shirking, and transferring some of these costs to outside shareholders. Distributing the firm's earnings to shareholders reduces agency costs by forcing the firm to sell new stock to fund the equity portion of the capital budget. Agency costs are assessed by new investors who impose a required rate of return on equity that is directly related to agency costs.

Shareholders incur transaction costs as long as the marginal increase in transaction costs is less than the marginal decrease in agency costs. This trade-off between transaction costs and agency costs leads many firms to distribute a portion of their earnings to shareholders and simultaneously sell new shares of stock.

Figure 1 illustrates the trade-off between transaction costs and agency costs. We define the equity distribution yield (EDY) as the percentage of a firm's market value distributed to shareholders through dividends and/or share repurchases during the year. We argue that the optimal equity distribution yield (EDY*) occurs where transaction costs plus agency costs are minimized. The following factors impact the cost curves and thus EDY*. 
Figure 1. Optimal Equity Distribution Model

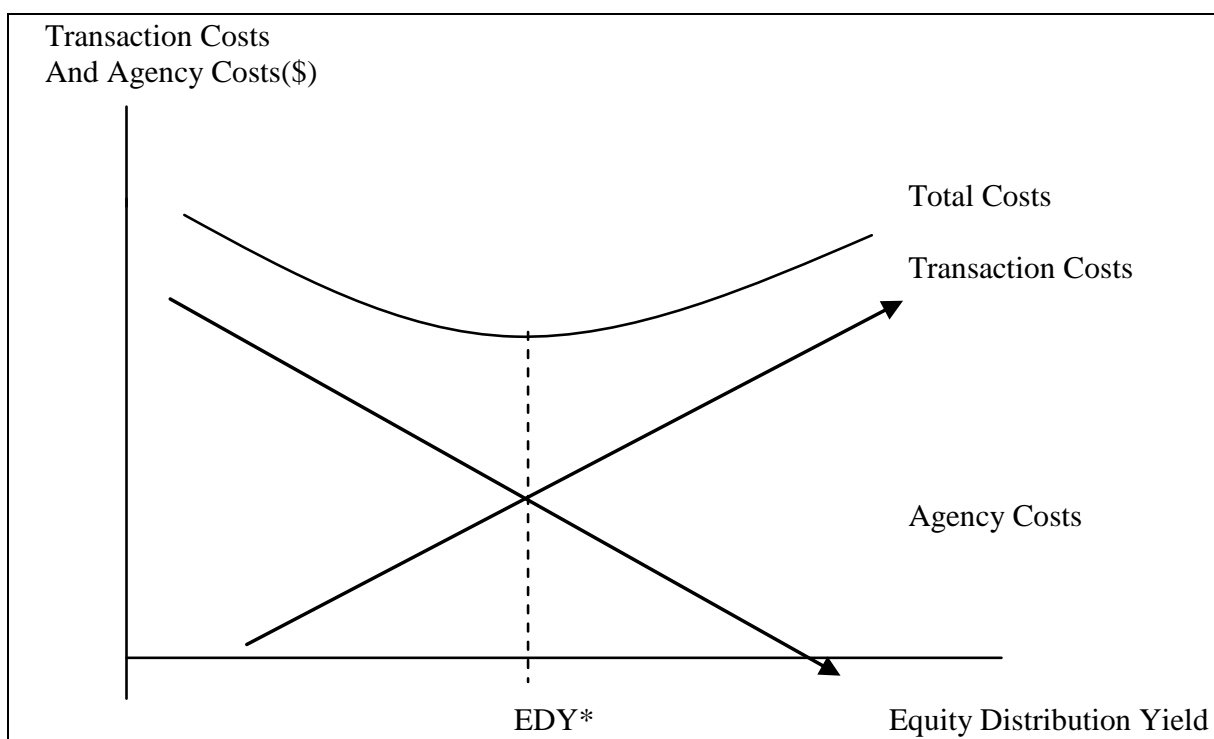

A firm's optimal equity distribution yield (EDY*) minimizes the sum of transaction costs and agency costs.

\subsection{Perceived Undervaluation}

The transaction cost curve of an undervalued firm may be to the right or to the left of the transaction cost curve of a fairly valued firm. On one hand, a seasoned offering for firms perceiving undervaluation will be costly because new stock will be sold at a price that is perceived by managers to be too low. Managers might choose a low equity distribution in order to reduce transactions costs associated with a new stock offering. On the other hand, Asquith and Mullins (1986), Vermaelen (1984), and Dann (1981) find that dividend and repurchase announcements send positive signals to investors who often respond by boosting the firm's stock price. Following this logic, firms that perceive undervaluation might take an aggressive approach and increase dividends and/or repurchases in order to send a credible signal to investors that will, management hopes, boost the stock price and eliminate undervaluation. This aggressive approach will make a new issue more likely, but also more efficient.

Our proxy for perceived undervaluation is the price-to-book value ratio (PB). This ratio is measured at the beginning of the year because dividends and share repurchases often send positive signals to investors, who typically respond by increasing the firm's market capitalization. The repurchase often reduces or eliminates perceived undervaluation. Measuring PB at the beginning of the year eliminates the positive feedback effect that repurchases have on valuation. In order to control for industry effects, PB is normalized by industry. Thus PB measures a firm's value relative to industry peers.

\subsection{Financial Leverage}

The more financial leverage a firm employs, the further to the left its transaction cost curve will be, and the firm will choose a lower EDY*, holding other factors constant. The trade-off model suggests that there is some optimum amount of financial leverage that is firm specific. Accordingly, under-leveraged (over-leveraged) firms can increase their value by financing with relatively more (less) debt. Paying higher dividends and/or repurchasing stock reduces equity and thus increases the debt ratio, holding all other things constant. Norgaard and Norgaard (1974) and Finnerty (1975) provide support for repurchasing firms altering capital structure to take advantage of increasing debt. As a proxy for financial leverage, this study uses a firm's debt-to-asset ratio (DA) normalized by industry. DA is measured at the beginning of the year in order to negate the effects equity cash distributions have on financial leverage. 


\subsection{Productivity of Assets}

The more productive a firm's assets are, the further to the right its transaction cost curve will be, and the firm will choose a higher $\mathrm{EDY}^{*}$, holding other factors constant. The earnings of firms with productive assets are likely to exceed capital budget requirements, and the surplus that results should be distributed to shareholders.

Similar to Stephens and Weisbach (1998), this study uses the cash flow-to-asset ratio (CF) normalized by industry as a relative measure of excess cash flow. Cash flow is defined as cash from operations plus depreciation and amortization.

\subsection{Investment Opportunities}

The fewer investment opportunities a firm has, the further to the right its transaction cost curve will be, and the firm will choose a higher EDY*, holding other factors constant. Firms with fewer investment opportunities will be likely to distribute more cash to shareholders. This study uses the firm's three-year growth rate in sales (GROW) to measure a firm's future investment opportunities.

\subsection{Firm Size}

The more owners a firm has, the further to the right its agency cost curve will be, and the firm will choose a higher EDY*, holding other factors constant. Perk consumption by owner-managers is likely to be more abusive if there is greater ownership dispersion. Rozeff (1982) uses the natural $\log$ of total number of shareholders to proxy for the dispersion of ownership in his study. To reduce missing data items, this study instead uses the natural $\log$ of market capitalization (CAP) to proxy dispersion of ownership. As a check for adequacy as a proxy, we estimate the correlation between the total number of shareholders and CAP to be 0.71 .

\section{Sample Selection}

Compustat is used to compile a sample of firms covering fiscal years 1996, 1997, and 1998. This three-year period is free from significant tax changes that could impact dividend policy as documented by Casey et al (1999) ${ }^{2}$. The sample begins with 22,506 observations (7,502 firms in the database multiplied by the three-year period). An initial screen eliminates firms with missing data items for either the price-to-book value ratio, debt-to-total asset ratio, cash flow plus depreciation and amortization value, three-year sales growth rate, or market capitalization value (10,529 observations eliminated). Next, repurchasing firms are eliminated from the sample if their Securities and Exchange Commission (SEC) form 10-K is unavailable on http://www.FreeEdgar.com (368 observations eliminated). Compustat aggregates common and preferred stock repurchases, and we are only interested in common stock repurchases. Therefore, a review of the firms' statement of cash flows eliminated those firms conducting preferred stock repurchases. ${ }^{3}$ The final sample includes 11,609 observations and represents 50 industries. Each firm's industry classification is based on the first two digits of its primary four-digit Standard Industrial Classification (SIC) code.

Table 1 presents means and medians of several variables for firms that make cash distributions to shareholders and those that make no cash distributions to shareholders. Approximately $47 \%$ of the firms distributed cash to shareholders during the period. Also, firms that made a distribution paid out approximately $2.12 \%$ of their market capitalization on an annual basis. This variable is skewed as the median distribution is $0.49 \%$.

Financial characteristics of distributing and non-distributing firms indicate that distributing firms have relatively higher cash flows (CF) and are larger (CAP) than non-distributing firms. These differences are significant when comparing either the means or medians. No significant differences in valuation (PB), financial leverage (DA), and growth rates (GROW) are apparent when comparing the medians of the two samples. We also note that equity distribution yields (EDYs) increased during the entire three years, with total distributions increasing potentially due to lack of alternative investment opportunities. The independent variables all exhibit minor differences during this same period. 
Table 1: Descriptive Statistics For Firms That Distribute Cash To Shareholders And Firms That Do Not Distribute Cash To Shareholders

\begin{tabular}{|c|c|c|c|c|c|c|}
\hline & \multicolumn{2}{|c|}{$\begin{array}{c}\text { Distributing Firms } \\
(5,467 \text { Firms })\end{array}$} & \multicolumn{2}{|c|}{$\begin{array}{c}\text { Non-Distributing Firms } \\
(6,142 \text { Firms })\end{array}$} & \multirow{2}{*}{$\begin{array}{c}\text { Differences in } \\
\text { Means }\end{array}$} & \multirow{2}{*}{$\begin{array}{c}\text { Differences in } \\
\text { Medians }\end{array}$} \\
\hline & Mean & Median & Mean & Median & & \\
\hline \multicolumn{7}{|c|}{ 1996-1998 } \\
\hline EDY (\%) & 2.12 & .49 & N/A & N/A & N/A & N/A \\
\hline $\mathrm{PB}(\%)$ & -.05 & -.30 & .05 & -.32 & $-5.36^{*}$ & 1.35 \\
\hline DA (\%) & -.06 & -.19 & .06 & -.19 & $-6.59 *$ & .16 \\
\hline $\mathrm{CF}(\%)$ & .27 & .13 & -.26 & -.20 & $30.32 *$ & $18.72 *$ \\
\hline GROW (\%) & 22.12 & 11.27 & 41.49 & 16.62 & $-3.74 *$ & -1.03 \\
\hline CAP & 2.40 & 2.39 & 1.63 & 1.61 & $45.30 *$ & $45.72 *$ \\
\hline \multicolumn{7}{|c|}{1996} \\
\hline EDY (\%) & 1.39 & 0.18 & N/A & N/A & N/A & N/A \\
\hline $\mathrm{PB}(\%)$ & -0.06 & -0.30 & 0.05 & -0.32 & $-3.43^{*}$ & 1.27 \\
\hline DA $(\%)$ & -0.06 & -0.16 & 0.06 & -0.18 & $-3.70 *$ & 0.73 \\
\hline $\mathrm{CF}(\%)$ & 0.27 & 0.14 & -0.23 & -0.15 & $16.18^{*}$ & $19.75^{*}$ \\
\hline GROW (\%) & 20.28 & 11.57 & 34.12 & 16.59 & $-4.13 *$ & -0.99 \\
\hline CAP & 2.42 & 2.42 & 1.61 & 1.59 & $27.57 *$ & $43.71 *$ \\
\hline \multicolumn{7}{|c|}{1997} \\
\hline EDY $(\%)$ & 1.89 & 0.33 & N/A & N/A & N/A & N/A \\
\hline $\mathrm{PB}(\%)$ & -0.04 & -0.31 & 0.06 & -0.31 & $-3.31 *$ & 0.14 \\
\hline DA (\%) & -0.05 & -0.20 & 0.06 & -0.21 & $-3.42 *$ & 0.42 \\
\hline $\mathrm{CF}(\%)$ & 0.28 & 0.14 & -0.26 & -0.21 & $18.48^{*}$ & $24.33^{*}$ \\
\hline GROW (\%) & 24.60 & 11.03 & 52.58 & 16.63 & -1.85 & -0.84 \\
\hline CAP & 2.44 & 2.44 & 1.66 & 1.66 & $27.15^{*}$ & $40.67 *$ \\
\hline \multicolumn{7}{|c|}{1998} \\
\hline EDY (\%) & 2.91 & 0.99 & N/A & N/A & N/A & N/A \\
\hline $\mathrm{PB}(\%)$ & -0.03 & -0.29 & 0.04 & -0.35 & $-2.44 *$ & 1.41 \\
\hline DA $(\%)$ & -0.06 & -0.22 & 0.08 & -0.18 & $-4.25^{*}$ & -0.98 \\
\hline $\mathrm{CF}(\%)$ & 0.26 & 0.10 & -0.30 & -0.28 & $18.59 *$ & $25.15^{*}$ \\
\hline GROW (\%) & 21.35 & 11.16 & 36.45 & 16.63 & $-5.16^{*}$ & -0.88 \\
\hline CAP & 2.35 & 2.34 & 1.61 & 1.58 & $24.50 *$ & $41.70 *$ \\
\hline
\end{tabular}

Notes: The table provides estimates of means and medians of six variables for firms that distribute cash to shareholders and firms that do not distribute cash to shareholders through either a share repurchase or a dividend distribution. Each variable is measured annually over a three-year period (1996-1998). EDY is the equity distribution yield, PB is the price-to-book value ratio normalized by industry, DA is the debt-to-asset ratio normalized by industry, CF is the cash flow-to-total asset ratio normalized by industry, GROW is the three-year sales growth rate, and CAP is natural $\log$ of market capitalization.

*Significant at the 0.01 level.

\section{Multivariate Analysis Of Repurchasing Determinants}

The equity distribution yield is a limited dependent variable because equity distributions cannot go below zero. Further, the sample data contain a mass of observations clustered at zero. For this reason, the following model is estimated using a standard one-limit Tobit model with censoring in the lower tail:

$\mathrm{EDY}=\alpha-\beta_{1} \mathrm{~PB}-\beta_{2} \mathrm{DA}+\beta_{3} \mathrm{CF}-\beta_{4} \mathrm{GROW}+\beta_{5} \mathrm{CAP}+\beta_{6} \mathrm{DUMMY} 97+\beta_{7} \mathrm{DUMMY} 98+\varepsilon$

where EDY is the equity distribution yield; PB is the normalized price-to-book value ratio; DA is the normalized debt-to-asset ratio; CF is the normalized cash flow-to-total asset ratio; GROW is the three-year sales growth rate; CAP is the natural log of market capitalization; DUMMY97 is a calendar year dummy variable (1997); and 
DUMMY98 is a calendar year dummy variable (1998). The calendar year dummies control for possible macroeconomic effects on dividend and share repurchase activity.

Table 2 displays the results of estimating equation 1. The second column in the table contains the estimated Tobit coefficients while the third column contains the estimated marginal effects. These marginal effects are evaluated at the mean value for each of the independent variables and account for the probability that a nondistributing firm might choose to repurchase conditioned on a change in each of the independent variables.

The coefficients all have the hypothesized signs and are significant at the $1 \%$ level with the exception of Dummy97. The marginal effects from the estimated Tobit model show a significant effect from perceived undervaluation. An increase in perceived undervaluation, as proxied by a drop in PB to one standard deviation below the industry average, would lead a firm to raise its equity distribution by $0.367 \%$. This result supports the hypothesis that a firm will increase its distributions to shareholders when managers perceive that the firm is undervalued.

Financial leverage (DA) is negatively related to equity distributions. A firm with a DA that is one standard deviation below the industry average would be expected to raise its equity distribution by $0.174 \%$. This result supports the idea that firms are motivated to make distributions in order to increase financial leverage.

Excess cash (CF and GROW) is positively related to equity cash distributions. One of our proxies for excess cash is CF. A firm with a CF that is one standard deviation above the industry average is expected to distribute $0.434 \%$ more of its market capitalization during the year. An increase in excess cash is also proxied by a decrease in the firm's sales growth rate. As the growth rate drops from $20 \%$ to $10 \%$, we estimate that its EDY will increase $0.02 \%$. Therefore, firms with more productive assets and fewer investment opportunities are motivated to repurchase stock. Although statistically significant, the equity payout response to a large change in growth rate is rather miniscule in the opposite direction. ${ }^{4}$ This finding supports "stable dollar dividend" policies for firms.

Finally, a firm's size (CAP) is positively related to equity distributions. If a firm's market capitalization increases from $\$ 200$ million to $\$ 300$ million, its EDY is expected to increase by $0.311 \%$ [(LN $300-$ LN 200)*0.767\}. This finding is consistent with the hypothesis that larger firms repurchase more of their market capitalization to reduce agency costs. This result is similar to Gaver and Gaver's (1993) finding that a firm's dividend yield is positively related to size.

\section{Conclusions}

The primary results in this paper show that firms increase cash distributions to shareholders if 1) firms perceive their stock price to be undervalued, 2) they use relatively little financial leverage, 3) they have more productive assets, 4) they have few investment opportunities, or 5) they have high agency costs. This study builds on Rozeff's (1982) work primarily by including share repurchases in the definition of equity distributions. We conclude that firms do have an optimal equity cash distribution policy that minimizes the sum of transaction costs and agency costs. The cross-sectional regularities that we find suggest that firms view total equity cash distributions as relevant.

\section{Suggestions For Future Research}

This area still provides avenues for fruitful research to determine what, if any, additional factors impact the equity distribution decision. Additional research questions arise in exploring how firms choose between share repurchases and dividend distributions. And a more recent post-2003 tax reform issue; Will these tax changes that alter the treatment of capital gains versus dividend income impact a firm's equity distribution decision? 
Table 2: Tobit Estimates of Cash Distributions to Shareholders

\begin{tabular}{|c|c|c|}
\hline $\begin{array}{l}\text { Independent } \\
\text { Variables } \\
\end{array}$ & $\begin{array}{l}\text { Coefficient } \\
\text { Estimates* } \\
\end{array}$ & $\begin{array}{c}\text { Marginal } \\
\text { Effects }(\%)\end{array}$ \\
\hline Constant & $\begin{array}{l}-11.209 \\
(-28.35) \\
\end{array}$ & -2.873 \\
\hline PB & $\begin{array}{l}-.1 .431 \\
(-10.11) \\
\end{array}$ & -0.367 \\
\hline DA & $\begin{array}{l}-0.678 \\
(-5.20) \\
\end{array}$ & -0.174 \\
\hline $\mathrm{CF}$ & $\begin{array}{c}1.694 \\
(11.75) \\
\end{array}$ & 0.434 \\
\hline GROW & $\begin{array}{c}-0.008 \\
(-5.78) \\
\end{array}$ & -0.002 \\
\hline CAP & $\begin{array}{c}2.994 \\
(20.91)\end{array}$ & 0.767 \\
\hline DUMMY97 & $\begin{array}{l}0.435 \\
(1.41) \\
\end{array}$ & 0.111 \\
\hline DUMMY98 & $\begin{array}{l}2.487 \\
(8.11) \\
\end{array}$ & 0.637 \\
\hline Sigma & $\begin{array}{c}6.120 \\
(77.39) \\
\end{array}$ & \\
\hline Log-likelihood & $-24,048$ & \\
\hline Scale factor for marginal effects & & 0.2563 \\
\hline Number of observations & 11,609 & \\
\hline Number of distributing firms & 5,467 & \\
\hline \multicolumn{3}{|c|}{$\begin{array}{l}\text { Notes: } \\
\text { This table displays estimates of the relation between equity cash distributions and variables likely to influence the distribution decision. The } \\
\text { dependent variable is the cash distribution-to-market value ratio measured annually over a three-year period (1996-1998). PB is the } \\
\text { normalized price-to-book value ratio; DA is the normalized debt-to-asset ratio; CF is the normalized cash flow-to-total asset ratio; GROW is } \\
\text { the three-year sales growth rate; CAP is the natural log of market capitalization; DUMMY97 is a calendar year dummy variable (1997); and } \\
\text { DUMMY98 is a calendar year dummy variable (1998). All data are gathered using Compustand notes to financial statements. The actual } \\
\text { equation estimated is a one-tailed Tobit model truncated at zero. The marginal effects }(\%) \text { for one standard deviation changes in the } \\
\text { independent variables in a Tobit model with left censoring are computed using } \\
\mathrm{E}[y \mid \mathbf{x}]=\Phi\left(\beta^{\prime} \mathbf{x} / \sigma\right)\left[\beta^{\prime} \mathbf{x}+\sigma \phi\left(\beta^{\prime} \mathbf{x} / \sigma\right) / \Phi\left(\beta^{\prime} \mathbf{x} / \sigma\right)\right] \text { with the vector of independent variables evaluated at the mean. Test } \\
\text { statistics are in parentheses. } \\
\text { *All coefficients have a P-Value of less than } 1 \% \text { with the exception of Dummy97 (15.86\%). }\end{array}$} \\
\hline
\end{tabular}

\section{Endnotes}

1. An anonymous reviewer correctly pointed out that one could consider share repurchases as more closely following a "passive residual" policy while not changing cash dividend payouts so as to not have to lower them in the future.

2. The period of analysis is a bull market. However, we expect the results to be similar during bear markets because of the expected positive relationship between cash flows (an independent variable in the model) and stock market returns. In a bear market we would expect repurchases to fall due to decreases in cash flows for many firms.

3. Additional analysis yields similar results when these firms are included.

4. An anonymous reviewer pointed out two competing theories that could explain the minimal equity payout response to changes in the growth rate. Higher payouts could signal a reduction in growth opportunities for the firm or, conversely could indicate greater confidence on the part of management.

\section{References}

1. Asquith, P., and D. W. Mullins, Jr., "Signaling with dividends, stock repurchases, and equity issues," Financial Management, Vol.15, pp.27-44, 1986. 
2. Bagwell, L. S., and J. B. Shoven, "Cash distributions to shareholders, Journal of Economic Perspectives," Vol.3, pp.129-140, 1989.

3. Bajaj, M., and A. Vijh, "Dividend clienteles and the information content of dividend changes," The Journal of Financial Economics, Vol. 26, pp.193-219, 1990.

4. $\quad$ Black, F., "The dividend puzzle," The Journal of Portfolio Management, Vol. 2, pp.5-8, 1976.

5. Brennan, M. J., "Taxes, market valuation and corporate financial policy," National Tax Journal Vol.23, pp.417-427, 1970.

6. Casey, K. M., D. C. Anderson, H. I. Mesak, and R. N. Dickens, "Corporate dividend policy and the 1986 Tax Reform Act," Financial Review Vol.34, pp.33-46, 1999.

7. Chaplinsky, S. and H. N. Seyhun, "Dividends and taxes: Evidence on tax-reduction strategies," The Journal of Business, Vol.63, pp.239-261, 1990.

8. Dann, L., "Common stock repurchases: an analysis of returns to bondholders and stockholders," The Journal of Financial Economics, Vol.9, pp.113-138, 1981.

9. Denis, David, Diane Denis, and A. Sarin, "Information content of dividend changes: Cash flow, signaling, overinvestment, and dividend clienteles," Journal of Financial and Quantitative Analysis, Vol.29, pp.567587, 1994.

10. Finnerty, J. E., “Corporate stock issue and repurchase,” Financial Management, Vol.4, pp.61-66, 1975.

11. Gaver, Jennifer J. and Kenneth M Gaver, "Additional Evidence on the Association Between the Investment Opportunity Set and Corporate Financing, Dividend and Compensation Policies," Journal of Accounting and Economics, Vol.16, pp.125-160, 1993.

12. Ikenberry, D., J. Lakonishok, and T. Vermaelen, "Market underreaction to open market share repurchases," The Journal of Financial Economics, Vol.39, pp.181-208, 1995.

13. Jensen, M. C., and W. H. Meckling, "Theory of the firm: Managerial behavior, agency costs and ownership structure," The Journal of Financial Economics, Vol.3, pp.305-360, 1976.

14. Kalay, A., "The ex-dividend day behavior of stock prices: a re-examination of the clientele effect," The Journal of Finance, Vol.37, pp.1059-1070, 1982.

15. Koch, P. D., and C. Shenoy, "The information content of dividend and capital structure policies," Financial Management, Vol.28, pp.16-35, 1999.

16. Lie, E., and H. J .Lie, "The role of personal taxes in corporate decisions: An empirical analysis of share repurchases and dividends," The Journal of Financial and Quantitative Analysis, Vol.34, pp.533-552, 1999.

17. Litzenberger, R. H. and K. Ramaswamy, "The effect of personal taxes and dividends on capital asset prices," The Journal of Financial Economics, Vol.6, pp.163-195, 1979.

18. Miller, M, "Behavioral rationality in finance: the case of dividends," The Journal of Business, Vol.59, pp.s451-s468, 1986.

19. Miller, M. and F. Modigliani, "Dividend policy, growth, and the valuation of shares," The Journal of Business, Vol.34, pp.411-433, 1961.

20. Miller, M. H. and M. Scholes, "Dividends and taxes," The Journal of Financial Economics, Vol.6, pp.333364, 1978.

21. Netter, J. M., and M. L. Mitchell, "Stock-repurchase announcements and insider transactions after the October 1987 stock market crash," Financial Management, Vol.18, pp.84-96, 1989.

22. Norgaard, R., and C. Norgaard, "A critical examination of share repurchases, Financial Management, Vol.3, pp.44-50, 1974.

23. Rozeff, M. S., "Growth, beta, and agency costs as determinants of dividend payout ratios," The Journal of Financial Research, Vol.5, pp.249-259, 1982.

24. Stephens, C.P., and M. S. Weisbach, "Actual share repurchase in open-market repurchase programs," The Journal of Finance, Vol.53, pp.313-333, 1998.

25. Vermaelen, T., "Repurchase tender offers, signaling, and managerial incentives," Journal of Financial and Quantitative Analysis, Vol.19, pp.163-181, 1984. 


\section{Do Not Print This Page!!}

\footnotetext{
${ }^{1}$ An anonymous reviewer correctly pointed out that one could consider share repurchases as more closely following a "passive residual" policy while not changing cash dividend payouts so as to not have to lower them in the future.

${ }^{2}$ The period of analysis is a bull market. However, we expect the results to be similar during bear markets because of the expected positive relationship between cash flows (an independent variable in the model) and stock market returns. In a bear market we would expect repurchases to fall due to decreases in cash flows for many firms.

${ }^{3}$ Additional analysis yields similar results when these firms are included.

${ }^{4}$ An anonymous reviewer pointed out two competing theories that could explain the minimal equity payout response to changes in the growth rate. Higher payouts could signal a reduction in growth opportunities for the firm or, conversely could indicate greater confidence on the part of management.
} 